How to cite this article:

Mustaffa, A., Awang, M. B., Nawang, N. I., \& Md Isa@Yusuff, Y. (2020). Preventive detention of children under Malaysian laws: A case for reform. UUM Journal of Legal Studies, 11(2), 97-116. https://doi.org/10.32890/uumjls.11.2.2020.8687

\title{
PREVENTIVE DETENTION OF CHILDREN UNDER MALAYSIAAN LAWS: A CASE FOR REFORM
}

\author{
${ }^{1}$ Aminuddin Mustaffa, ${ }^{2}$ Mohd Badrol Awang, \\ ${ }^{3}$ Nazli Ismail Nawang \& ${ }^{4}$ Yusramizza Md Isa @ Yusuff \\ ${ }^{1,2 \& 3}$ Faculty of Law \& International Relations, \\ Universiti Zultan Zainal Abidin, \\ ${ }^{4}$ School of Law, Universiti Utara Malaysia, Malaysia \\ 1Corresoponding author: aminuddinm@unisza.edu.my
}

Received: 10/2/2020 Revised: 31/5/2020 Accepted: 10/6/2020 Publsihed: 31/7/2020

\begin{abstract}
Preventive detention refers to the incarceration of an individual who has not yet been convicted, to prevent him from causing harm or endangering the community in some unspecified way. It can be seen as the deprivation of an individual's liberty based on the belief that he may be a danger to others. The issue of preventive detention of children is quite controversial and has attracted debate among various legal scholars. In Malaysia, provisions contained in specific statutes that aim to prevent terrorism or threats to national security have been invoked to justify the preventive detention of children. The practice and application of these statutory provisions on children have been subjected to various criticisms. This paper aims to analyze current Malaysian laws pertaining to the preventive detention of children. It encompasses qualitative research of doctrinal and comparative nature. It will critically analyze legal issues in this area with reference to international standards and practices of other legal systems. The study concludes that the legal reform of the current Malaysian legal framework on this aspect is urgently needed
\end{abstract}


to protect the rights and interests of children during the juvenile justice processes. Therefore, the study provides recommendations towards the improvement of the existing laws and policies on the preventive detention of children.

Keywords: Children, preventive detention, criminal proceedings.

\section{INTRODUCTION}

Preventive detention refers to the detention of a person for an unspecific duration of time without trial. This is in contrast with punitive detention, where a person is detained after due process of law has taken place, upon which a person has been legally proven to have committed an offence punishable under criminal law. ${ }^{1}$ Preventive detention violates the theory of punishment as it imposes punishment on a person before he is proven guilty by a court of law. This evidently contradicts a fundamental principle of criminal law, namely that a person is presumed innocent until proven guilty. In the matter of children, the impact of preventive detention on them can be quite harmful. Preventive detention without trial may not only deny them of their fundamental right of liberty, but may also cause deprivation of social life, healthcare and personal development, denial of educational opportunities and stigmatization. (Mccarthy, 1987). ${ }^{2}$

This article aims to analyze the preventive detention of children under Malaysian laws with reference to international standards as set by international instruments. It employs a qualitative research methodology that engages both doctrinal and comparative methods. A doctrinal method is adopted as a means of assessing a relevant body of law as well as legal principles governing preventive detention of children. In addition, a comparative method enables the authors to critically examine the consistency of Malaysian law with the international standards set out by international instruments, particularly on the aspect of the preventive detention of children. The paper is based on data that is sourced from peer-reviewed literature and databases of regulatory authorities.

\footnotetext{
1 Minister of Home Affairs, Malaysia \& Ors v. Datuk James Wong Kim Min [1976] 1 LNS 129.
} 
The first part of this article briefly discusses basic legal principles relating to preventive detention. The second part of this paper outlines the international standards on the preventive detention of children. The third part analyses the legal position on the preventive detention of children under the current Malaysian laws. It examines provisions of specific laws which allow for the preventive detention of children, grounds for its justification, possible remedies, and the approaches adopted by the courts in determining the validity of the detention. The final part of this paper proposes recommendations towards the improvement of the current Malaysian juvenile justice system specifically with regards to this controversial area of law.

\section{INTERNATIONAL STANDARDS}

The issue of detention of children is a matter of great interest and attention on the international platform, as evidenced by the various international instruments that are currently in place. Guidelines which contain specific provisions on this matter are provided under both international and regional instruments, among them are the United Nations Convention on the Rights of Children (CRC), the United Nations Standard Minimum Rules for the Administration of Juvenile Justice (Beijing Rules), and the United Nations Rules for the Protection of Juveniles Deprived of their Liberty (Havana Rules). The international standards laid down by these international instruments are very important as they serve as comprehensive guidelines towards the development of national legal frameworks on this particular area in all jurisdictions. These international instruments have outlined at least four main principles pertaining to the detention of children.

\section{A Measure of Last Resort and for the Shortest Appropriate Period of Time}

The international instruments have emphasized that the detention of children shall only be used as a measure of last resort ${ }^{3}$ and only for the shortest appropriate time ${ }^{4}$. This requirement is clearly set

\footnotetext{
3 Article 37(b) of the CRC, Rule 2 of the Havana Rules and Rule 19.1 of the Beijing Rules.

4 Article 37(b) of the CRC.
} 
out under the CRC, the Havana Rules, and the Beijing Rules. This requirement also places the burden on the detaining authority to satisfy a double test in order to legally justify the detention. The first test requires the detaining authority to prove that the intended detention is carried out as a last resort. It must be proven that the detention is legally justified as the case cannot be suitably dealt with in any other way that will not require the detention of children. If the first test is met, the next test demands the detaining authority to determine the shortest appropriate period of detention time that is necessary.

In explaining this requirement, the Committee on the CRC ("the Committee") stresses that it is the responsibility of state parties to ensure that their respective national laws appropriately reflect the requirements of the international standards. The national laws should, as much as possible, ensure that any criminal cases involving children should be given priority and disposed of speedily. This is to avoid the cases of unnecessarily prolonged detention of children pending trial. Pursuant to that, the Committee has specifically outlined guidelines on the time frame of cases involving children. The Committee states that cases of children who are placed under detention be handled within a period of thirty days (Committee on the Rights of the Child, 2007). It also imposes responsibility on the judicial body to dispose of the case within six months after the case is formally registered.

As an alternative solution to deal with backlog cases of detained children, the Committee suggests state parties to develop alternative measures such as diversion, warnings, community service, and rehabilitative programs to divert children from the formal criminal justice process. The use of alternative measures, which are informal in nature, may avoid and protect children from the effect of the formal criminal process such as stigmatization, recidivism, labeling, and others.

\section{Special Rules and Procedures}

The international instruments stress the need to provide special rules and procedures in dealing with the detention of children. In line with the cardinal principle of law that a person is innocent until 
proven guilty, any child detained before trial should be treated in a proper manner. Article 37 of the CRC underline that children under detention should be treated in a fair, proper manner, and with respect to personal dignity, taking into consideration the needs of persons of their age. The same requirement is also stipulated under Rule 13.4 of the Beijing Rules and Rule 17 of the Havana Rules. Elaborating on this requirement, the Committee strongly recommends state parties to set up separate detention centres for children and adults. The main purpose of this requirement is to prevent children from being exposed to negative elements which may influence them if they are allowed to have direct contact with adult detainees.

Apart from that, the Committee also emphasizes on the need to introduce special policies and practices at the separate detention centre designated for children (Committee on the Rights of the Child, 2007). It recommends that a separate detention centre for children should be equipped with special facilities that are specifically designed for children and handled by professionally trained staff. In addition, the Havana Rules propose children to be detained at special detention centres that impose very minimal security measures. ${ }^{5}$ This recommendation is intended to minimize the negative effects of detention such as stigmatization and depression among detained children. Apart from that, it is also recommended that children detained at the detention centre should be allowed to continue their studies or training. These international instruments have placed a huge responsibility on the states to ensure that children are given opportunities to receive the necessary education and vocational training that are suitable for their interests, age, gender, and character. ${ }^{6}$ In view of this, the state parties are responsible to ensure that the detention centres are equipped with adequate educational facilities and qualified staff such as vocational instructors, child specialists, expert trainers, counselors, and others.

In addition, international instruments recommend for the effective and direct participation of parents or guardians in any criminal process concerning children placed under detention and deprived of liberty (Committee on the Rights of the Child, 2007). The parents' involvement in this respect should not be viewed as interference

Rule 30.

6 Rule 13 of the Beijing Rules and Rule 18 of the Havana Rules. 
with the due process of law, but instead as necessary to protect the interests of detained children by affording them physical, psychological, and emotional assistance. Children under detention are always in dire need of these kinds of support and assistance as they are fundamentally lacking of physical and emotional capacity, experience, and maturity. In view of this, the Committee stresses that special arrangements and rules should be set when dealing with children placed under detention. In terms of location, it is recommended that a detained child should be sent to the detention centre that is close to the residence of his family (Committee on the Rights of the Child, 2007). The rules and procedures concerning the visiting rights of parents and guardians should be relaxed to ensure that parents and guardians are given more flexible access to their detained children. This kind of arrangement will enable parents or guardians to maintain close relations and contact with their children throughout the period of detention.

\section{Arbitrariness and Lawfulness}

The international instruments impose strict conditions to be fulfilled concerning detention and deprivation of liberty of children. The CRC provides that the detaining authority should not detain any child unless it passes the tests on arbitrariness and lawfulness. ${ }^{7}$ Both requirements have a distinct meaning and have to be met cumulatively. The requirement of lawfulness places emphasis on the need to comply with the grounds and procedures set under domestic laws. In other words, any detention of children must be lawful in the sense that it strictly complies with the principles of both substantive and procedural laws. On the other hand, the test of arbitrariness focuses on elements beyond the principle of legality, including the reasonableness of the law itself and proportionality of measures (Schabas \& Sax, 2006). It simply means that the decision to resort to the detention of children must meet the requirement that it is not only reasonable but also proportionate, taking into consideration all circumstances and conditions.

\section{Produce Before a Judge or a Court}

The international instruments provide that any detained child shall be immediately produced before a judge or a court which is

7 Article 37 of the CRC. 
authorized by law without any delay. ${ }^{8}$ This right is automatic and it must be afforded to any detained child immediately after the detention, regardless of whether he requests for it or not. It also means that the detaining authority has no discretionary power to prevent any detained child from being produced immediately before a judge or a court. This is to enable the detained child to exercise his right to challenge the validity of the detention. It also aims to ensure that the detention of any child is made with strict adherence to legal requirements, free from any abuse or violation of the due process of the law. While elaborating on this matter, the Committee has highlighted that any detained child shall be produced before the court or other competent authority within twenty-four hours of his detention (Committee on the Rights of the Child, 2007). The court or other competent authority before which the case is brought is under a duty to determine the matter and promptly decide on its lawfulness and legality. ${ }^{9}$ In addition, the court or other competent authority is also under an obligation to provide reasons for their decisions relating to the application for detention. This is to enable the detained child to further exercise his right to file an appeal against the decision of the court concerning his detention.

It should be noted that any detained child who is brought before the court to determine the lawfulness of his detention is entitled to be represented by a legal practitioner. To guarantee this fundamental right, the CRC stipulates that any detained child shall be given the right to consult a legal practitioner at the earliest possible time after detention. In the event the child is unable to obtain legal services due to financial problems, the CRC specifies that it is mandatory for the state parties to appoint a legal counsel for him and pay for legal costs. This requirement is laudable as detained children should not be expected to represent themselves in any legal proceedings before the courts, which are typically strict, complex, and technical.

In short, issues concerning the detention of children have always been regarded as a matter of great concern. This being the case, the international instruments have laid down specific international standards to be followed in dealing with cases of deprivation of liberty and detention of children. These international standards are

Article 37(d).

Article 37(d) of the CRC. 
vital as they serve as a benchmark for any legal system in framing their national laws on the detention of children.

\section{PREVENTIVE DETENTION UNDER MALAYSIAN LAW}

The issue of preventive detention of children under Malaysian law always attracts attention from various parties, simply because it is most inappropriate to detain any child who has not yet been found guilty. This practice has been vehemently criticized as it seriously violates the principles of human rights. According to existing records, a total of 142 children have been detained under the Prevention of Crime Act (POCA) 2013 as of 2017 (Zainal, 2019). This high number of children detained in prison without trial indicates a growing reliance on preventive detention in dealing with juvenile crimes in Malaysia. Apart from that, the treatment of children under preventive detention at the detention centres has also become a matter of great concern. In a report by the Human Rights Commission of Malaysia (SUHAKAM), it was disclosed that there were thirty-nine children detained without trial under POCA in Kluang Prison during their visit there in July 2018 (SUHAKAM, 2018). The interviews conducted by SUHAKAM with some of the detained children revealed allegations of various mistreatments of child detainees in the form of police brutality and forced confession. In addition, SUHAKAM also disclosed that the detained children had lodged complaints that they were beaten and abused during the investigation, were refused proper medical treatment, and were prohibited from seeing their families (Landau, 2019).

\section{Laws on Preventive Detention}

As far as Malaysian law is concerned, there are two governing statutes concerning juvenile justice processes in Malaysia, namely the Child Act 2001 and the Criminal Procedure Code (CPC). The CPC is a general statute governing criminal processes and procedures under Malaysian law. Meanwhile, the Child Act 2001 is a specific statute that is applicable to any child, who is defined as a person below the age of eighteen-years-old. The Act was enacted to govern various legal matters relating to children, including criminal processes. However, it is worth noting that provisions of the Child 
Act 2001 pertaining to criminal processes, in Part X and part XI, are not comprehensive. In the absence of specific or clear provisions in the Child Act 2001 on any matter relating to the criminal processes, reference has to be made to the CPC. Section 11(6) of the Child Act 2001 , clearly permits the application of the provisions of the CPC in the absence of specific provisions providing for special or different procedures in the Child Act 2001.

In terms of the principles and procedures of arrest and detention of children, reference needs to be made to both the Child Act 2001 and the CPC. The Child Act 2001 lays down the powers of the police to arrest and detain a child suspected of committing any crime for investigation. ${ }^{10}$ It states that police may detain any suspected child for the period of twenty-four hours. If the circumstances of the case require the police to detain any suspected child suspect for more than twenty-four hours, they must apply for a remand order from the magistrate. The procedures for remand are not provided under the Child Act 2001. The application for remand is made before the magistrate. In deciding the application, the magistrate shall scrutinize whether there are well-founded grounds to believe the accusation and information made against the suspect. The magistrate is duty-bound to state grounds for his decision to allow or reject the application. This procedure needs to be duly observed in all cases dealing with the arrest and detention of children.

However, there is an important exception to the above-mentioned provisions. The principles and procedures stipulated under the Child Act 2001 and the CPC are not applicable to cases in which children are detained pursuant to the preventive detention order. The special procedures relating to preventive detention can be found under the specific statutes that allow for preventive detention orders in the first place. There are several statutes under Malaysian law that give power to the Minister, the authorized board, or the police to issue a preventive detention order against a specific person for a certain period of time, on the basis of preventing security offences or terrorist activities. Among these statutes are the Prevention of Terrorism Act 2015 (POTA), the Prevention of Crime Act (Amendment and Extension) 2014 (POCA), and the Security Offences (Special Measures) Act 2012 (SOSMA).

10 Section 84 of the Child Act 2001. 
It is important to note that provisions of the specific statutes relating to preventive orders prevail over the provisions of the CPC and the Child Act 2001. To illustrate this point, reference can be made to the decision of the court in the case of Chong Boon Pau v the Minister of Home Affairs \& 3 Ors. ${ }^{11}$ In this case, the validity of a detention order without trial issued by the Minister of Home Affairs under the Emergency (Public Order and Prevention of Crime) Ordinance 1969 was challenged by the accused. It was argued that the order was invalid as it contravened the provisions of the Child Courts Act 1947. The Federal Court held that the provisions of the Ordinance prevail over the provisions of the Child Courts Act 1947. As such, the detention order issued by the minister in exercising his power under the said Ordinance was valid. ${ }^{12}$ This decision clearly indicates that a child can be detained under the preventive order issued by the Minister or authorized board, regardless of the provisions of the Child Act 2001.

\section{The Application of Laws on Preventive Detention}

The preventive detention of children on the grounds of national security or prevention of crimes is a very controversial matter. The application of these draconian laws on children has been subjected to strong criticisms by various parties on the grounds that these are oppressive and violate the right to personal liberty. It is argued that the right to personal liberty is a fundamental right guaranteed under the Federal Constitution (Masum, 2010).

SOSMA is a procedural law that lays down the procedures to be followed when a security offence has been committed under certain statutes such as the Penal Code, the Special Measures Against Terrorism in Foreign Countries Act 2015, and the Anti-Trafficking in Persons and Anti-Smuggling of Migrant Act 2007. Section 4(5) of the SOSMA empowers the police to detain any individual for a maximum of twenty-eight days without trial on the grounds of involvement in security offences. The provision under SOSMA, which has been subjected to heavy criticism by various parties, merely requires the police officer concerned to "have reason to

\footnotetext{
11 [1980] 1 MLJ 154.

12 Chong Boon Pau v. Timbalan Menteri Dalam Negeri [2004] 4 CLJ 838 .
} 
believe" of the suspect's involvement in security offence to justify the detention (Wood, 2014). Apart from that, SOSMA also contains provisions which allow the police officer concerned to act merely upon the belief or suspicion of the suspected person's "involvement" in the offence, without the need to prove the actual commission of the offence itself ("Pass of the Security Offences Bill", 2012). In its criticism of SOSMA, the Malaysian Bar Council argued that the application of its provisions has deliberately deprived a detained person of exercising his fundamental rights as well as procedural safeguards, which are enshrined under the Federal Constitution and the CPC (Thomas, 2012).

Similarly, the application of POTA and POCA has been vehemently criticized by various parties as being deliberate violations of the principles of fundamental liberty of an individual. They are seen as undermining the provisions of the Federal Constitution (Sivalingam, 2015). POTA empowers the Prevention of Terrorism Board to issue a detention order against any individual on the grounds of involvement in terrorism activities. The term of the detention order is for a period not exceeding two years. However, the Board may further renew the term if they believe that such detention is necessary on the grounds of public security, public order, or prevention of crimes. ${ }^{13}$ There are various criticisms lamented against this Act. The vagueness of the terms used in POTA leaves it open to the possibility of abuse and misuse of power. The absence of clear definitions of the terms employed in POTA, such as the words "engaged," "commission," "support," and "involving," make them susceptible to various interpretation, rendering almost anyone a possible target of the statute. In addition, a person detained under POTA is also deprived of his/her fundamental rights to be represented by a legal practitioner of his/her own choice and the right to be informed of the grounds of arrest. Worse, any decision made by the Prevention of Terrorism Board pursuant to POTA cannot be challenged by way of judicial review in any court. Describing POTA as a blatant breach of the principles of fundamental liberty, SUHAKAM has strongly criticized the Government for this piece of legislation and has demanded it to be reviewed (SUHAKAM, 2015).

Meanwhile, POCA allows for the preventive detention of a person on the basis of prevention of crime. It empowers the Prevention of

13 Section 13. 
Crime Board to order the detention of an individual for a term not exceeding two years. However, the Prevention of Crime Board may order an extension of the detention term for a period not exceeding two years at a time, if deemed necessary.

\section{Remedy}

The Federal Constitution of Malaysia guarantees individuals certain fundamental rights. Article 5 (2) of the Federal Constitution provides a constitutional remedy in the sense that it allows a person deprived of his liberty to bring a proceeding before the court to challenge the lawfulness of his detention. However, such a constitutional right is not absolute as it may be curtailed in two instances, as provided under Article 149 and Article 150 of the Federal Constitution. Article 149 confers power to the Parliament to pass special laws against subversion and acts which are prejudicial to public order, whilst Article 150 enables the Yang di-Pertuan Agong to issue a proclamation of emergency. Both articles allow the enactment of legislation, even if they are inconsistent with certain fundamental liberties guaranteed under Part II of the Federal Constitution. Regardless, there have been various instances where the detainees have filed proceedings before the court to challenge the lawfulness of the detention.

As regards to children detained under preventive detention, a general remedy available to them is to file a judicial review, normally by way of application for a writ of habeas corpus (Shair \& Ahmad, 2013). It is a writ that requires the detaining authority to produce a person detained before the court for the purpose of reviewing and determining legality and lawfulness of the detention. The main purpose of a habeas corpus application is to release any person who is unlawfully detained by the detaining authority. However, it should be noted that a detention order made pursuant to POTA and POCA cannot be challenged by way of judicial review before the court. Section 15A of POTA and Section 19 of POCA prohibits judicial review of any act done or decision made by the Prevention of Terrorism Board and the Prevention of Crime Board respectively in the exercise of their discretionary powers, except on procedural grounds. In other words, both provisions appear to take away the fundamental right of the detained child to challenge the lawfulness 
of the detention by simply ousting the power of the court to review decisions made by the respective Boards. It is also unfortunate to note that the definition of the term "judicial review" under both Acts includes habeas corpus. As such, any child detained under a preventive order made pursuant to either POTA or POCA is legally prevented from bringing proceedings by way of judicial review to challenge the lawfulness of their detention.

\section{Approach of the Courts}

Reference to decided cases indicates that the scope of judicial review has been interpreted restrictively by the Malaysian courts. It seems that the courts consistently refuse to interfere with the decision of the executive to issue the detention order against any person(s). Adopting a literal and restrictive view, the courts have firmly and consistently maintained that the courts have no power to review any act or decision of the minister or the decision-maker except in cases of non-compliance with any procedural requirement. The reluctance of the courts to review the minister or the decision-maker's decision is essentially based on the doctrine of separation of powers laid down in the Federal Constitution (Khaira, 2007). This principle is well explained by the Federal Court in the case of Karam Singh $v$. Menteri Hal Ehwal Dalam Negeri. ${ }^{14}$ Suffian FJ, while delivering judgment, opined as follows:

\section{"Whether or not the fact on which the order of detention is to be based are sufficient or relevant, is a matter to be decided solely by the executive. In making their decision, they have complete discretion and it is not for a court of law to question the sufficiency or relevance of these allegations of fact."}

The Federal Court further emphasized that the executive has the complete and exclusive discretion to decide and issue a detention order based on the presented facts. Therefore, it is not permissible for the court of law to question the sufficiency or relevance of such allegations of fact. As such, the duty of the court in proceedings relating to preventive detention orders is narrowly restricted to the procedural aspect of the exercise of the executive discretion. As a

$14 \quad[1969] 2$ MLJ 129. 
result, the courts have consistently continued to adhere to outdated ideas and rigid principles in deciding on the application of judicial review.

Such an approach adopted by the Malaysian courts has been subjected to discussion by legal practitioners and scholars. It has been argued that the judiciary, as a protector of the fundamental liberties, should adopt a more liberal approach in deciding matters relating to its power to review the legality of detention orders (Shair \& Ahmad, 2014). It has been suggested that the judiciary should interpret the ouster clauses in such a way so as not to take away its power of reviewing the legality of detention orders completely, given that judicial review is an extremely important mechanism for the judiciary to uphold and preserve the rule of law and to protect individual rights and liberties (Naz \& Sabaruddin, 2016). Therefore, it is time for the courts to depart from their reluctance to challenge and invalidate executive actions in issuing preventive detention orders. Instead, the courts, as the guardian of justice, should uphold their legal authority and be more prepared to claim and assert its power of judicial review to examine the executive's orders on constitutional grounds or violation of the rules of natural justice.

\section{REFORM}

The preceding paragraphs discussed the current Malaysian laws on preventive detention of children for an indefinite period of time. Examination of provisions of certain specific statutes that provide for preventive detention on the grounds of prevention of terrorism and security offences, has clearly confirmed that children can be subjected to preventive detention in a similar way to adults. This legal position is far from satisfactory as it deliberately violates the principles of fundamental rights and breaches the rules of natural justice. In addition, it is unfortunate to note that the existing laws on this matter have not made any specific reference to children in terms of the application of preventive detention laws. It impliedly shows that the lawmakers have not recognized and this has defied various research findings by scientists and psychologists which have convincingly revealed that children and adults are fundamentally different in terms of development: physical, mental, emotional, 
maturity, and experience (Choudhury et al., 2006). These findings should be given due consideration in the formulation of law as it clearly justifies the need to provide a special set of law or at least special treatment in terms of the application of the law for children. Failure to take into consideration this peculiar fact may render any legal measure or approach being implemented as incomprehensive, ineffective, and misapplied, which is contradictory to the fundamental concept of fairness and justice under rule of law.

Apart from that, the application of these draconian laws clearly contravenes the standards outlined by international instruments. It should be emphasized that the international instruments clearly require that any arrest of a child should be avoided as much as possible in any circumstances. It shall only be used only as the last option and if necessary, for the shortest appropriate period of time. Preventive detention of children without trial is also viewed as completely contradictory to the requirement of due process of law stipulated by the international instruments, which states that no child shall be deprived of his liberty unlawfully or arbitrarily. Clearly, current Malaysian laws on preventive detention of children do not measure up to the international standards. It is pertinent to note that on 17th February 1995, the Government of Malaysia had ratified the $\mathrm{CRC}$, an international instrument on the rights of children. As a signatory to the $\mathrm{CRC}$, it is certainly important for the Government of Malaysia to consistently show their continuous commitment towards meeting the requirements of the $\mathrm{CRC}$, including the matter of the fundamental liberties of children.

In short, it can be summed up that the current Malaysian laws, practices, and policies on this matter are undesirable as they do not conform to fundamental principles of liberty, natural justice and international standards. The reform of law in this area is absolutely necessary and urgently needed.

\section{Abolishment of Laws}

The best option that can be taken in order to reform the existing laws in this area is to completely abolish the preventive detention of children. Amendments should be made to all relevant statutes that allow for the preventive detention of children, namely SOSMA, 
POCA, and POTA by inserting specific provisions that expressly exclude the application of preventive detention without trial on children. It is worth emphasizing that preventive detention should never be resorted to in handling children as it may cause significantly harmful and far-reaching effects on children physically, mentally, emotionally, and psychologically. It is timely for the Government of Malaysia to develop alternative measures that focus on informal methods to deal with children in conflict with the law. In other words, it is inappropriate to impose preventive detention without trial on children. Instead of detaining a child for an indefinite period of time, there are a variety of alternatives measures that can be resorted to in dealing with them, such as mediation, community service, probation order, counseling, vocational training programs, and others. These alternative measures, which promote restoration and rehabilitation of children, should be availed for the best interest of children. The achievement of justice demands the children's legal empowerment which not only endorses and engages the fundamental rights of children but also builds bridges to legal and other interventions to support them (Mousavi et al., 2014).

\section{Amendment of Laws}

If the Government of Malaysia decides to maintain the application of preventive detention on children, amendments should be made to certain aspects of existing laws in order to ensure that their rights to due process of the law are recognized and guaranteed. First, it is suggested that provisions of relevant statutes, particularly POTA and POCA which disallow detention orders under those statutes to be subjected to judicial review except on procedural grounds should be amended. The existence of such ouster clauses under both statutes have unfairly denied the children detained under preventive detention their right to due process of law as they have no opportunity to challenge the validity of their detention. This position is completely unsatisfactory as it clearly violates the fundamental principles of fairness and justice.

Second, it is recommended that special rules and procedures be introduced should the government decide to maintain existing laws that allow for the preventive detention of children. This is consistent with the requirements of international standards that demand each 
state to establish a separate and special set of rules and procedures dealing with children in conflict with the law. The main purpose of this requirement is to accommodate children's specific needs and interests, in line with the aim of juvenile justice. For example, the proposed special rules may clearly stipulate that preventive detention of children should only be chosen as an option of the last resort, in line with the requirement of the international instruments. The duty and burden lie with the authority that has power to issue the detention order to ensure the existence of valid and concrete grounds that warrant the detention of children as necessary and justifiable. In terms of the duration of preventive detention, it is pertinent to ensure that the detention is only for the shortest period of time. As for the place of detention, children should be detained at specialised detention centres separate from the adults. It is also necessary to ensure that the specialised centres for detention of children are wellequipped with the appropriate facilities and professionally trained staff that are able to handle the detention of children.

Based on the above discussion, it is pertinent to assert that there is an urgent need and cogent basis for the government of Malaysia to either abolish or reform existing laws relating to the preventive detention of children.

\section{CONCLUSION}

The use of preventive detention on children indefinitely on the grounds of prevention of future crime and terrorism activities is not in line with the principles of the best interest of children. The negative impact of detention on them can be far-reaching, taking into consideration their age, maturity and level of physical, mental and psychological development. It is timely for the Malaysian Government to review the current legal framework on the preventive detention of children and to treat it as a matter of utmost urgency. The way children are handled at various stages of criminal proceedings is important as it indirectly reflects society's perception of them. As a signatory to the CRC, the Government of Malaysia should strive towards fulfilling its commitment to uphold the CRC's requirements, including the aspect of fundamental liberty of children. Therefore, it is crucial for the Government of Malaysia to earnestly pay attention 
to criticisms on this issue and to call for the reform of existing laws in this area.

\section{ACKNOWLEDGEMENTS}

This research is funded by Universiti Sultan Zainal Abidin through Dana Penyelidikan Universiti (UniSZA/2017/DPU/50).

\section{REFERENCES}

Amor, Daniel. (2002). The e-business ( $R$ ) evolution: Living and working in an interconnected world. Upper Saddle River, N.J.; London: Prentice Hall PTR.

Cher, L. S. (2015). Putrajaya Snubbed International Calls to Halt POTA, Says Bar President. The Malaysian Insider. Retrieved from http://www.themalaysianinsider.com

Chong Boon Pau v Timbalan Menteri Dalam Negeri [2004] 4 CLJ 838.

Committee on the Rights of the Child, General Comment No 10: Children's Rights in Child Justice, CRC/C/GC/10, 25 April 2007, para. 81 .

Committee on the Rights of the Child, General Comment No 10: Children's Rights in Juvenile Justice, CRC/C/GC/10, 25th April 2007, para. 85.

ECtHR, Case of McKay v the United Kingdom (App. No. 543/03), judgment 3 October 2006, at para. 34 .

Gan, C. (1995). The Implementation of the Internal Security Act of Malaysia: An Analysis of the Protective Measures Available and Their Effectiveness. Current Law Journal, 1, 1-13.

Goldson, B., \& Kilkelly, U. (2013). International human rights standards and child imprisonment: Potentialities and limitations. The International Journal of Children's Rights, 21, 345-371.

Goldson, B., \& Muncie, J. (2012). Towards a global "child-friendly" juvenile justice? International Journal of Law, Crime, and Justice, 40(1). 47-64.

Human Rights Commission of Malaysia (SUHAKAM). (2018). Human Rights Commission of Malaysia Annual Report 2018. Kuala Lumpur. 
Human Rights Commission of Malaysia (SUHAKAM). (2015). Human Rights Commission of Malaysia Annual Report, Kuala Lumpur.

Khaira, H. S. (2007). Preventive Detention: Part I Constitutional Rights and The Executive. Malayan Law Journal, 1, 1xiiilxxxi.

Khaira, H. S. (2007). Preventive Detention: Part II. Malayan Law Journal, 4, cxxxii-cxlv.

Landau, E. (2019, January 30). SUHAKAM, SUARAM call for review on laws for juvenile detention. New Strait Times. Retrieved from https://www.nst.com

Lee Kew Sang v Timbalan Menteri Dalam Negeri [2005] 3 CLJ 914.

Lippke, R. L. (2014). Preventive pre-trial detention without punishment. Res Publica, 20(2), 111-127.

Loganathan, K. (2005). The shifting sands of judicial minds in relation to article 8 of the federal constitution. Current Law Journal, 5, i-ix.

Masum, A. (2010). The doctrine of judicial review: A cornerstone of good governance in Malaysia. Malayan Law Journal, 6, cxiv-cxxxix.

Mccarthy, B. R. (1987). Preventive detention and pretrial in the child court custody. Journal of Crime and Justice, 15, 185-200.

Mohd Faizal Harris v Timbalan Menteri Dalam Negeri Malaysia \& Ors [2006] 1 MLJ 309.

Mousavi, S., Yusoff, J. Z. M., Dusuki, F. N., \& Rastegari, B. (2014). A critical legal analysis on the minimum age of criminal responsibility in the new Islamic punishment act of Iran. UUM Journal of Legal Studies, 5, 31-50.

Naz, S., \& Sabaruddin, J. S. (2016). Malaysian preventive detention laws: Old preventive detention provisions wrapped in new packages. Malaysian, JMCL, 43(2), 59-78.

Noor Ashid bin Sakib v Ketua Polis Negara [2001] MLJ 393.

Pei Keng, Y. (1995). Preventive detention under ISA-unlawful for non-violent peaceful activities: The effect of the recent important federal court decision in Chor Phaik Har v. Farlim Properties Sdn. Bhd. on Statutory Interpretation. Current Law Journal, 1, cxcv.

Minister of Home Affairs, Malaysia \& Ors v Datuk James Wong Kim Min [1976] 1 LNS 129. 
Sajad Husin Wani v Ketua Pengarah Imigresen \& Satu Lagi [2008] 2 CLJ 403.

Schabas, W., \& Sax, H. (2006). Article 37. Prohibition of Torture, Death Penalty, Life Imprisonment and Deprivation of Liberty. In A. Alen et al. (Eds.), A Commentary on the United Nations Convention on the Rights of the Child. Leiden: Martinus Nijhoff Publishers.

Shair Mohamed, M. A., \& Ahmad, A. S. (2013). Habeas corpus and the Malaysian courts: Strange bedfellows? The Malaysian court's approach to issues pertaining to detention. Law Review, 357-376.

Shair Mohamed, M. A., \& Ahmad, A. S. (2014). The quest for the protection of liberty and executive detention: The constitution and the constitutional remedy. Law Review, 1-21.

Sivalingam, J. (2015, May 16). Bar begins campaign to repeal antiterror law. The Star. Retrieved from http://www.thestar.com. my

Stewart, H. (2013). The right to be presumed innocent. Criminal Law and Philosophy, 8(2), 407-420.

Suara Rakyat Malaysia. (2012). Pass of the Security Offences Bill (Special Measures) 2012, Will Cause More Travesty of Justice and Violations of the Rights of Malaysian Citizens for Years to Come. Retrieved from http://www.suaram.net

Thomas, T. (2012, April 21). Is the security offences bill constitutional? The Malaysian Insider. Retrieved from http:// www.themalaysianinsider.com

UNICEF.(2013). The Malaysian juvenile justice system: A study of mechanisms for handling children in conflict with the law. Kuala Lumpur.

Uthayakumar a/l Ponnusamy v Menteri Keselamatan Dalam Negeri \& Anor [2004] 5 CLJ 328.

Wood, S. (2014). The Operation of the Security Offences (Special Measures) Act 2012 and a Comparison with the Old Internal Security Act 1948. Heralding a New Democratic Era, or Old Wine in a New Bottle? International Journal of Technical Research and Applications, 10,78-83.

Zainal, F. (2019, Jan 30). SUHAKAM, SUARAM: Release Juveniles Detained Without Trial Under POCA. The Star. Retrieved from https://www.thestar.com.my 